


\title{
ANÁLISE E AVALIAÇÃO \\ DA APLICAÇÃO DOS \\ INSTRUMENTOS JURÍDICOS E \\ URBANÍSTICOS PARA RESGATE \\ DA CIDADANIA EAPLICAÇÃOO \\ DA FUNÇÃO SOCIAL DA \\ PROPRIEDADE: O CASO DA VILA \\ NOVO OURO PRETO'
}

\author{
ANALYSIS AND EVALUATION OFTHE IMPLEMENTATION OF \\ LEGAL INSTRUMENTS FOR URBAN RECOVERY OF \\ CITIZENSHIP AND APPLICATION OFTHE SOCIAL FUNCTION \\ OF PROPERTY: THE CASE OF VILA NOVO OURO PRETO
}

Alfio Conti ${ }^{2}$ - Cristiane Locatelli - Cristiane Martins - José Mário B. Alves ${ }^{3}$ - Marco Antonio Souza Borges Netto ${ }^{4}$ - Margarete M. A. Silva ${ }^{5}$ - Marina Beatriz Tello Oliveira ${ }^{6}$

\section{Resumo}

O artigo relata a experiência da comunidade da Vila Novo Ouro Preto, ressaltando o papel dos instrumentos legais e urbanísticos que estão à disposição das comunidades carentes, e o potencial do conhecimento e apropriação desses instrumentos. Após um breve histórico da experiência, destacando a importância da mobilização comunitária e das parcerias com a sociedade civil e o terceiro setor, além daquelas com o próprio Poder Público, são discutidos os instrumentos legais urbanísticos, de cunho nacional e municipal, que podem ser empregados, objetivando sua aplicação caso a caso. Ao final, será traçado um quadro que servirá para a legitimação jurídico-legal das reivindicações e buscas da comunidade da Vila Novo Ouro Preto, servindo como referência para outras comunidades e para quem, jurista, queira assessorar essa parcela de população urbana.

Palavras-chave: Autogestão; Habitação; Assentamentos informais; Cidadania.

\footnotetext{
Abstract

The Vila Novo Ouro Preto - VNOP, located in Belo Horizonte, is a rare example of how a community aware of its problems and potentials can overcome social barriers imposed on them by society. To achieve such a result was fundamental recognition and study of the environment and their local conditions along with the internalization of self-management philosophy and the availability and use of new urban tools as ways to solve their own problems.Keywords: Self-management, housing, citizenship
} 